\title{
MOLECULAR IDENTIFICATION OF Liriomyza sp. IN THE NORTHEAST AND SOUTHEAST REGIONS OF BRAZIL ${ }^{1}$
}

\author{
ELAINE CRISTINA BATISTA FERREIRA ${ }^{2}$, MOISES THIAGO DE SOUZA FREITAS ${ }^{3 *}$, \\ KARLA DIANA DA SILVA SOMBRA ${ }^{2}$, HERBERT ÁLVARO ABREU DE SIQUEIRA ${ }^{2}$, \\ ELTON LUCIO DE ARAUJO ${ }^{4}$, VALDIR DE QUEIROZ BALBINO ${ }^{3}$
}

\begin{abstract}
In Brazil, species of the genus Liriomyza are widely distributed and have economic importance as they cause damage to at least 14 plant families, especially Solanaceae, Cucurbitaceae, Asteraceae, and Fabaceae. Studies suggest existence of a species complex within this genus, based on the presence of morphological similarities among the species Liriomyza trifolii (Burgess), L. sativae Blanchard and L. huidobrensis (Blanchard). The present study aimed to use DNA barcoding to establish new distribution records of L. sativae in distinct regions in Brazil, determine intra- and inter-population genetic diversity, and reconstruct the phylogeny of Liriomyza species using the DNA barcode sequences. Identity values were between $97 \%$ and $99 \%$, confirming that all the examined Brazilian populations belonged to the species $L$. sativae. Phylogenetic analyses indicated the presence of a single clade of L. sativae, composed of seven populations. Intra-population analysis on individuals of these populations indicated low levels of nucleotide and haplotype diversity. The haplotype network indicated presence of only 14 haplotypes distributed among the Brazilian populations. The genetic similarities shared by the Brazilian populations of L. sativae suggest that these populations are closely related. Genetic patterns observed among populations of L. sativae might be associated with bottleneck events or founder effect during establishment of this leafminer in Brazil.
\end{abstract}

Keywords: Cryptic species. DNA barcoding. Population genetics.

\section{IDENTIFICAÇÃO MOLECULAR DE Liriomyza sp. NAS REGIÕES NORDESTE E SUDESTE DO BRASIL}

\begin{abstract}
RESUMO - No Brasil, as espécies do gênero Liriomyza têm importância econômica e são amplamente distribuídos no país, causando danos a pelo menos 14 famílias de plantas, especialmente Solanaceae, Cucurbitaceae, Asteraceae e Fabaceae. Estudos sugerem a existência de um complexo de espécies dentro deste gênero com base na presença de semelhança morfológica nas espécies Liriomyza trifolii (Burgess), L. sativae (Blanchard) e L. huidobrensis (Blanchard). Este estudo teve como objetivo empregar o DNA Barcode em novas áreas para estabelecer novos registros de Liriomyza sativae no Brasil e também a determinação da diversidade genética intra e interpopulacional, e reconstruir a filogenia das espécies Liriomyza utilizando sequências do DNA barcode. Os valores de identidade foram entre $97 \%$ a 99\%, confirmando que as todas as populações brasileiras avaliadas pertencem à espécie L. sativae. A análise filogenética indicou a presença de um único clado de L. sativae composto pelas sete populações. A análise intrapopulacional indicou níveis baixos de diversidade nucleotidica e haplótipica de indivíduos dessas populações. A rede de haplótipos indicou a presença de apenas 14 haplótipos distribuídos entre populações brasileiras. As semelhanças genéticas compartilhadas pelas populações brasileiras de L. sativae sugere que essas populações estão intimamente relacionados. Os padrões genéticos observados em populações de L. sativae pode estar associada a eventos gargalos ou efeito fundador durante o estabelecimento deste minadora no Brasil.
\end{abstract}

Palavras-chave: Espécies crípticas. DNA barcoding. Genética de Populações.

\footnotetext{
${ }^{*}$ Corresponding author

${ }^{1}$ Received for publication in $07 / 26 / 2016$; accepted in 02/13/2017.

Paper extracted from the Master's degree dissertation of the first author.

${ }^{2}$ Department of Agronomy, Universidade Federal Rural de Pernambuco, Recife, PE, Brazil; laynecristina17@hotmail.com, karladssombra@hotmail.com, herbert.siqueira@pq.cnpq.br.

${ }^{3}$ Department of Genetic, Universidade Federal de Pernambuco, Recife, PE, Brazil; moisesfrts@gmail.com, vqbalbino@gmail.com.

${ }^{4}$ Department of Plant Sciences, Universidade Federal Rural do Semi-Árido, Mossoró, RN, Brazil; elton@ufersa.edu.br.
} 


\section{INTRODUCTION}

During larval development, several species of Diptera exhibit mining habits - a common feature of the family Agromyzidae, especially species of the genera Liriomyza and Agromyza (WIEGMANN et al., 2011). The species Liriomyza trifolii (Burgess), L. sativae (Blanchard), and L. huidobrensis (Blanchard) are a cause for concern because they damage several crops (MURPHY; LASALLE, 1999). The wide distribution of these pests and their expansion into new geographic areas has led to damaged agro-ecosystems due to overuse of pesticides (FERGUSON, 2004; WAN et al., 2015).

Infestation by miner species reduces the quality of vegetable crops and consequently, their commercial value, resulting in economic losses to farmers. According to Parrella (1987), these pests can damage crops in several ways: destruction of plants and reduction in crop yields, quality of fruit trees, and aesthetic value of ornamental plants. Leaf miner species are well established in agricultural areas worldwide, causing great damage to a large number of plant species of economic importance. It is believed that these insects have expanded to new geographical areas through vegetable commercialization (SPENCER, 1973; REITZ; GAO; LEI, 2013).

Several insect groups of agricultural importance belong to a species complex, making identification by classical taxonomy a challenge, even for the experts (BUSVINE, 1980; DELLA TORRE et al., 2002; CLARK et al., 2005). Since the 1970s, mitochondrial DNA (mtDNA) has been an important part of studies involving genetic structure, phylogeny, and biogeography and used in the comprehension of biological and evolutionary aspects of several organisms (WILSON et al., 1985). Among the mitochondrial genes, Cytochrome Oxidase subunit I ( $\operatorname{cox} I)$ has been widely used in phylogeny. Hebert et al. (2003) proposed the use of a cox $I$ fragment as a DNA barcode, useful for identifying various metazoan groups. DNA barcoding has been used to identify different species of insect pests, endemic and non-endemic, and their natural enemies (GARIEPY et al., 2007). It is a reliable, quick technique that can be applied at any developmental stage of all insects (JENKINS; CHAPMAN; MICALLEF, 2012; DE SOUZA FREITAS et al., 2015). In Liriomyza spp., DNA Barcoding has been applied successfully to differentiate between the main species (KOX et al., 2005; SCHEFFER; MATTHEW; RAVINDRA, 2006; BLACKET et al., 2015).

In Brazil, three species of the genus Liriomyza (L. sativae, L. huidobrensis and L. trifolii), with a distribution in the northeast, central-west and southeast regions of the country, have been identified based on morphological characters (SPENCER, 1973). Despite the species distribution records in Brazil, identification of Liriomyza spp. can be confusing because of the morphological similarities between different species and the large number of common hosts (PARRELLA et al., 1982). Genetic and biological studies done in other populations of Liriomyza spp. have also suggested existence of a species complex (SCHEFFER; LEWIS, 2005). Therefore, new techniques have been implemented in identification of Liriomyza spp. (KOX et al. 2005; BLACKET et al. 2015). Among these techniques, the DNA barcoding has enormous potential for identification of cryptic species (GARIEPY et al., 2007; JENKINS; CHAPMAN; MICALLEF, 2012; HEBERT et al., 2003).

In the present study, DNA barcoding was employed to establish new distribution records of the vegetable leafminer $L$. sativae, in northeast and southeast Brazil. Moreover, we evaluated the intra- and inter-population genetic diversity and reconstructed the phylogeny of Liriomyza spp. specimens from all populations.

\section{MATERIAL AND METHODS}

\section{Field collection of Liriomyza spp.}

The specimens were reared from the vegetable leafminers collected in field, from several host species in northeast and southeast Brazil (Table 1). Adult specimens were preserved in $95 \%$ ethanol and maintained at $-20{ }^{\circ} \mathrm{C}$. All field specimens were identified by genetic analysis.

\section{DNA extraction, PCR, and DNA sequencing}

Extraction of genomic DNA was carried out using Chelex ${ }^{\circledR} 100$ (BioRad, Berkeley, California, USA), following the methodology employed by Costa-Junior et al. (2015). Using the Diptera-specific degenerated primer pair HCO2198-L (5'-TAAACTTCWGGRTGWCCAAARAATCA-3') and LCO1490-L (5' GGTCWACWAATCATAAAGATATTGG-3') (NELSON; WALLMAN; DOWTON, 2007), a cox I gene fragment of $707 \mathrm{bp}$ was amplified. Amplification was performed using the $\mathrm{GoTaq}^{\circledR}$ Colorless Master Mix, according to the manufacturer's specifications (Promega, Fitchburg, Wisconsin, USA). PCR products were visualized in $1 \%$ agarose gel with UV light and purified using the Wizard $^{\circledR} \quad$ SV Gel and PCR Clean-Up System (Promega, Fitchburg, Wisconsin, USA). Sequencing was carried out on ABI 3500 automatic sequencer 
(Applied Biosystems, Cleveland, Ohio, USA). Only the sequences with a Phred score (EWING et al., 1998) above 30 were used in the analysis. Contig assembly was carried out using CodonCode Aligner (CodonCode Corporation). Local alignments were performed using BLAST (ALTSCHUL et al., 1990). All new sequences produced in this study were deposited in GenBank under accession numbers KT851558 to KT851663.

Table 1. Liriomyza spp. specimen collection sites in northeast and southeast Brazil.

\begin{tabular}{|c|c|c|c|c|c|}
\hline Municipalities, State & Abbreviation & Regions & Coordinates (Lat.; Long.) & $\mathrm{N}$ & Host \\
\hline Jaguaruana, Ceará & $\mathrm{JAG}_{\mathrm{mel}}$ & Northeast & $4^{\circ} 50^{\prime} 02^{\prime \prime} \mathrm{S} ; 37^{\circ} 46^{\prime} 52^{\prime \prime} \mathrm{W}$ & 20 & Melon \\
\hline Mossoró, Rio Grande do Norte & $\mathrm{MOS}_{\mathrm{mel}}$ & Northeast & $5^{\circ} 11^{\prime} 17^{\prime \prime} \mathrm{S} ; 37^{\circ} 20^{\prime} 39^{\prime \prime} \mathrm{W}$ & 19 & Melon \\
\hline Gravatá, Pernambuco & $\mathrm{GRA}_{\text {tom }}$ & Northeast & $8^{\circ} 12^{\prime} 35^{\prime \prime} \mathrm{S} ; 35^{\circ} 34^{\prime} 10^{\prime \prime} \mathrm{W}$ & 15 & Tomato \\
\hline \multirow[t]{2}{*}{ Camocim de São Felix, Pernambuco } & $\mathrm{CAM}_{\text {tom }}$ & Northeast & $8^{\circ} 21^{\prime} 34^{\prime \prime} \mathrm{S} ; 35^{\circ} 45^{\prime} 50^{\prime \prime} \mathrm{W}$ & 8 & Tomato \\
\hline & $\mathrm{CAM}_{\text {bean }}$ & Northeast & & 10 & Bean \\
\hline Juazeiro, Bahia & $\mathrm{JUA}_{\mathrm{mel}}$ & Northeast & $9^{\circ} 26^{\prime} 18^{\prime \prime} \mathrm{S} ; 40^{\circ} 30^{\prime} 19^{\prime \prime} \mathrm{W}$ & 18 & Melon \\
\hline Venda Nova do Imigrante, Espírito Santo & $\mathrm{VNI}_{\text {tom }}$ & Southeast & $20^{\circ} 20^{\prime} 6^{\prime \prime} \mathrm{S} ; 41^{\circ} 07^{\prime} 49^{\prime \prime} \mathrm{W}$ & 16 & Tomato \\
\hline Total & & & & 106 & \\
\hline
\end{tabular}

$\mathrm{N}=$ number of specimens sequenced.

\section{Phylogenetic analyses}

Nucleotide sequences were aligned using MUSCLE (EDGAR, 2004), incorporated in MEGA v. 6.0 (TAMURA et al., 2011). Phylogenetic analysis was carried out with the maximum likelihood criterion, using PhyML (GUINDON et al., 2010). The evolutionary model that best fit the data was HKY $+\mathrm{G}$, according to the jModelTest analysis (POSADA, 2008). We also constructed phylogenetic trees by the neighbor-joining method (SAITOU; NEI, 1987), using Kimura's two-parameter correction (KIMURA, 1980), incorporated in the MEGA Software (TAMURA et al., 2011). The consistency of branches was assessed using 1,000 bootstrap replicates. Sequences of $L$. sativae (KF962593), L. huidobrensis (EF104703), L. trifolii (GU327644), Phytomyza ranunculivora (EU367538), and P. rufipes (EF494670) were used as out groups.

\section{Genetic diversity}

Genetic diversity between populations was estimated based on the haplotype and nucleotide diversities, $\mathrm{K}$ value (number of genetic groups), number of polymorphic sites, and number of transitions and transversions, as determined by DnaSP v. 4.0 and Arlequin v. 3.5 (ROZAS et al., 2003; EXCOFFIER; LISCHER, 2010). Tajima's $D$ neutrality test (TAJIMA, 1989) was performed using Arlequin v. 3.5 (EXCOFFIER; LISCHER, 2010). Genetic differentiation between populations was assessed using pairwise fixation index $F_{S T}$, as determined by Arlequin v. 3.5 (EXCOFFIER; LISCHER, 2010).

Total number of nucleotide substitutions per site $\left(D_{\mathrm{a}}\right)$, average number of nucleotide substitutions per site $\left(D_{\mathrm{xy}}\right)$, average nucleotide pairwise difference $(K x y)$, number of shared polymorphisms $\left(S_{\mathrm{s}}\right)$, and number of fixed differences $\left(S_{\mathrm{f}}\right)$ between two populations were calculated using DnaSP v. 4.0 (ROZAS et al., 2003). A haplotype network was created with NETWORK v. 4.6 (http://www.fluxusengineering.com), using the median-joining method (BANDELT; ROHL, 1999), to examine the level of haplotype sharing and distribution frequency among populations.

\section{RESULTS AND DISCUSSION}

A total of 106 specimens were analyzed. Sequence analysis of the cox $I$ gene fragment (707 bp) showed $15(\sim 2.1 \%)$ polymorphic sites, which comprised eight ( $53.3 \%)$ parsimony-informative sites and seven ( 46.7\%) singletons. Among the polymorphic sites, $86.7 \%$ of the nucleotide substitutions were transitions and $13.3 \%$ were transversions. Indels were not observed. All nucleotide substitutions observed were synonymous.

Comparative analyses for all sequences obtained in this study were performed through BLASTn (basic local alignment search tool- nucleotide), using the NCBI non-redundant sequence database. We observed identity values between $97 \%$ and $99 \%$ for L. sativae (Data not shown). These values confirmed that all specimens examined in this study belonged to the species $L$. sativae. Previously, specimens of the genus Liriomyza from the Mossoró region (Rio Grande do Norte, northeast Brazil) were identified as L. sativae, through DNA sequencing of the cox I gene (LIMA; 
GEREMIAS; PARRA, 2009). Our study demonstrated that DNA barcoding could be useful for molecular identification of $L$. sativae in areas where there are other cryptic species in sympatry (e.g., L. huidobrensis and L. trifolii). Accurate identification of the Liriomyza spp. has become relevant for the establishment of appropriate control methods, because the levels of resistance to different insecticides might differ between species of leafminers (TOKUMARU et al., 2005).

Phylogenetic analyses by maximum likelihood or neighbor-joining showed very high similarity, revealing a single clade well supported by bootstrap values of $96 \%$ and $92 \%$, respectively (Figures 1 and 2). These results reinforce the idea that the populations of $L$. sativae from northeast and southeast regions exhibit low levels of genetic diversity. Moreover, the separation of the L. sativae specimens in a single clade with significant support values, with respect to other members of this complex, indicates that the collection sites in northeast and southeast Brazil exhibit individuals of a single species. In previous studies, $L$. sativae populations from Philippines, using DNA barcoding (SCHEFFER; MATTHEW; RAVINDRA, 2006), had also reported a single clade of $L$. sativae. The phylogenetic analysis is also supported by previously described morphological differences among $L$. sativae, L. huidobrensis, and L. trifolii (SPENCER, 1973). In Brazil, studies related to evolutionary relationships of the Liriomyza spp. are limited, demonstrating the importance of this study for the field.

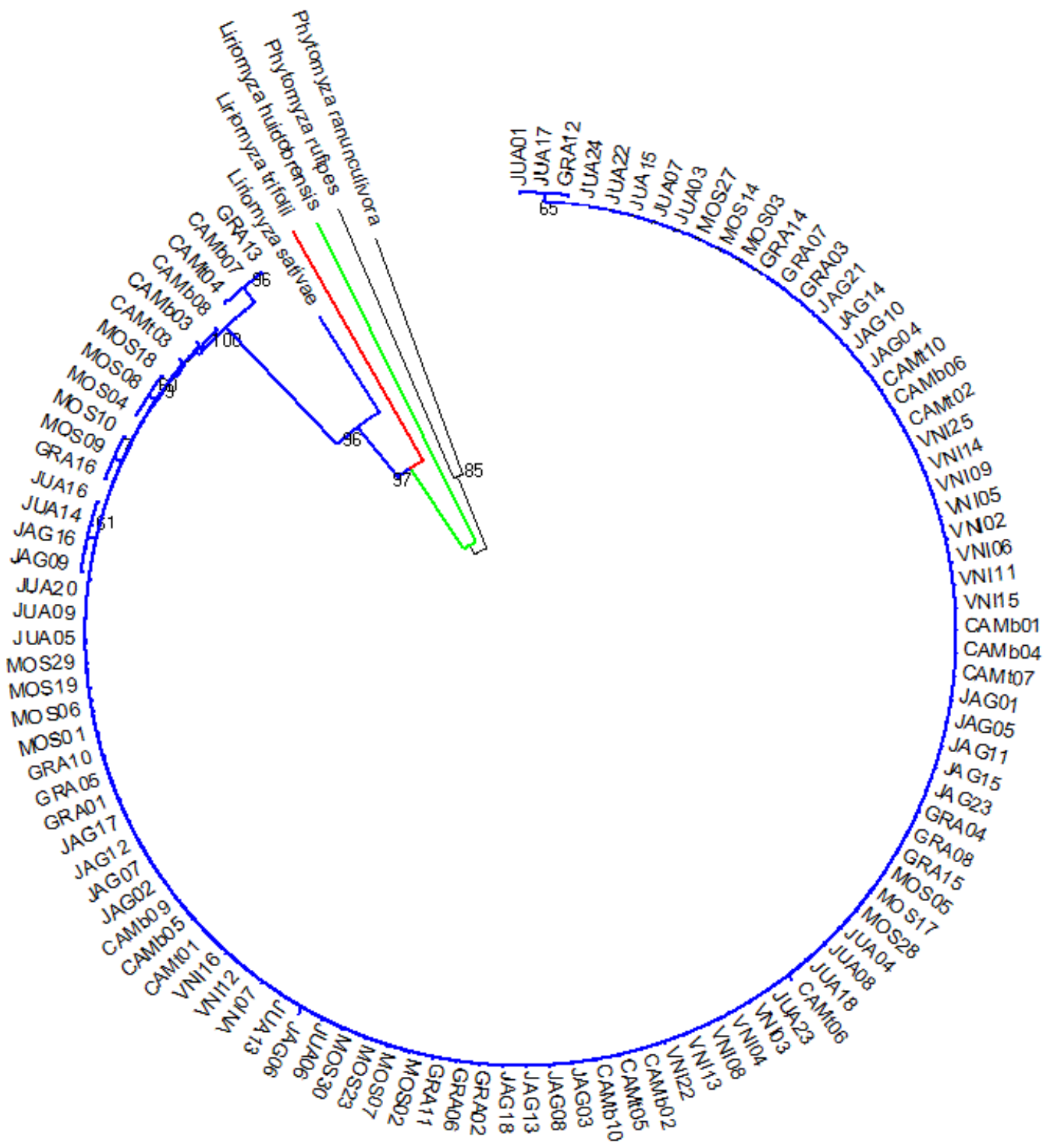

Figure 1. Phylogenetic analysis of Liriomyza sativae specimens using the Cytochrome oxidase subunit I (cox I) locus. A rooted maximum likelihood tree was generated with the HKY $+\mathrm{G}$ model and 707 bp cox I sequences. VNI= Venda Nova do Imigrante-ES; CAM= Camocim de São Felix-PE; CAM=Camocim de São Felix-PE; JAG= Jaguaruana-CE; GRA= Gravatá-PE; MOS= Mossoró- Rio Grande do Norte; JUA= Juazeiro-BA. 


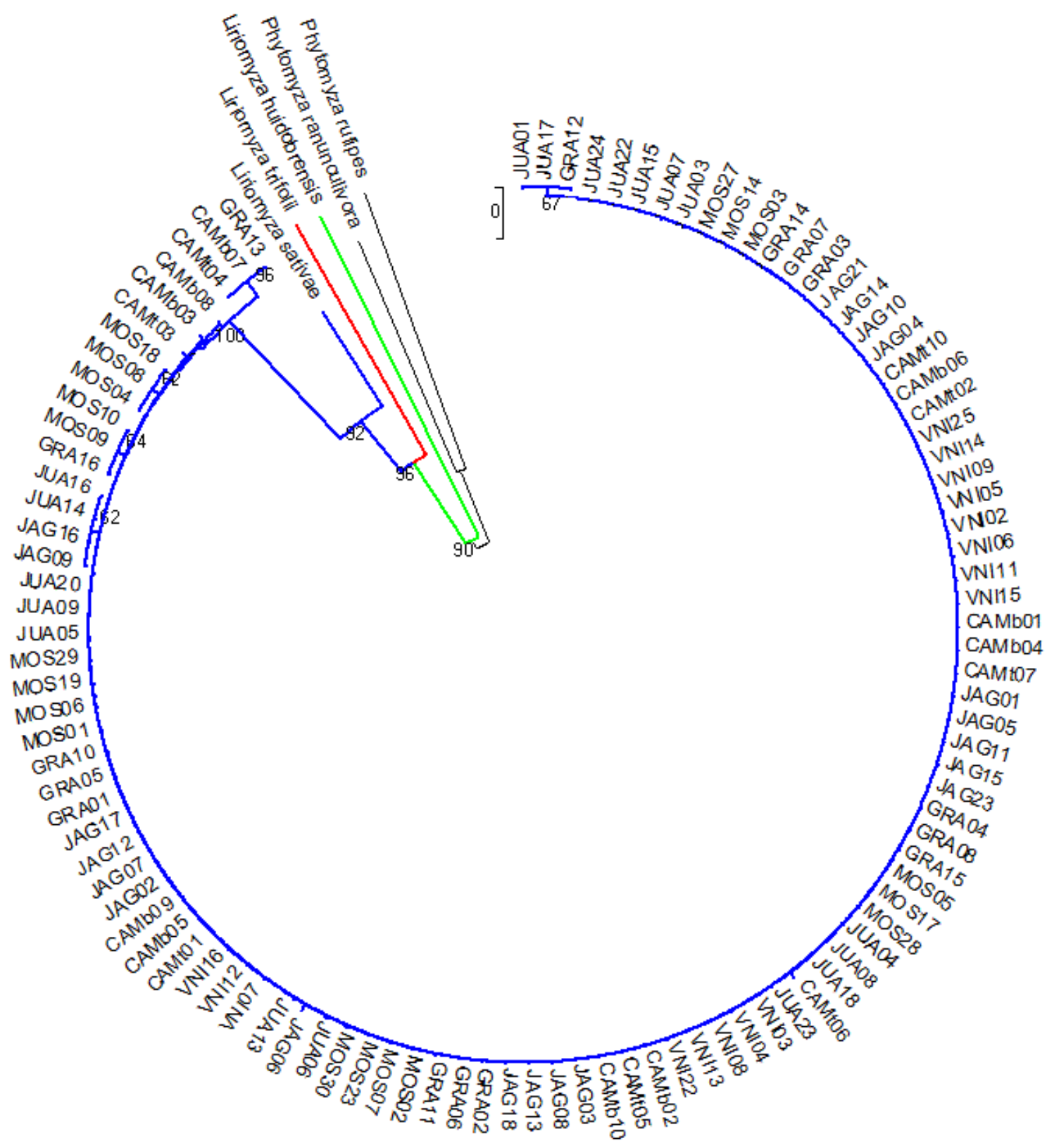

Figure 2. Phylogenetic analysis of Liriomyza sativae specimens using the Cytochrome oxidase subunit I (cox I) locus. A rooted neighbor-joining tree was generated with the Kimura's two-parameter model and 707 bp cox I sequences. $\mathrm{VNI}=$ Venda Nova do Imigrante-ES; $\mathrm{CAM}=$ Camocim de São Felix-PE; CAM=Camocim de São Felix-PE; $\mathrm{JAG}=$ Jaguaruana-CE; GRA= Gravatá-PE; MOS= Mossoró- Rio Grande do Norte; JUA= Juazeiro-BA.

The haplotype network indicated presence of 14 haplotypes (Figure 3). The most frequent haplotype (H_1) was shared by 81 individuals distributed among the seven populations studied. The populations $\mathrm{CAM}_{\text {bean }}$ and $\mathrm{CAM}_{\text {tom }}$ exhibited four exclusive haplotypes, which suggests that the host species could affect the genetic differentiation patterns in L. sativae.

The intra-population analysis revealed intermediate haplotype diversity and low nucleotide diversity for the examined populations (Table 2). In addition, the populations exhibited low levels of genetic differentiation, which reflects the absence of genetic structure in the Brazilian $L$. sativae populations. Tajima's $D$ test was negative and nonsignificant $(\mathrm{P}<0.05)$ for all populations, indicating that the observed polymorphism was due to neutral mutations (Table 2). Genetic analysis revealed a non-significant difference between the Brazilian populations of $L$. sativae examined in this study. However, despite close proximity, the genetic diversity between the $\mathrm{CAM}_{\text {tom }}$ and $\mathrm{CAM}_{\text {bean }}$ populations (from tomato and bean plantations, respectively, from Camocim de São Felix in northeast Brazil) was higher than that between other populations (Table 2), suggesting a probable host-pest relationship, as described in other studies (PANG et al., 2005; WANG et al., 2008). 


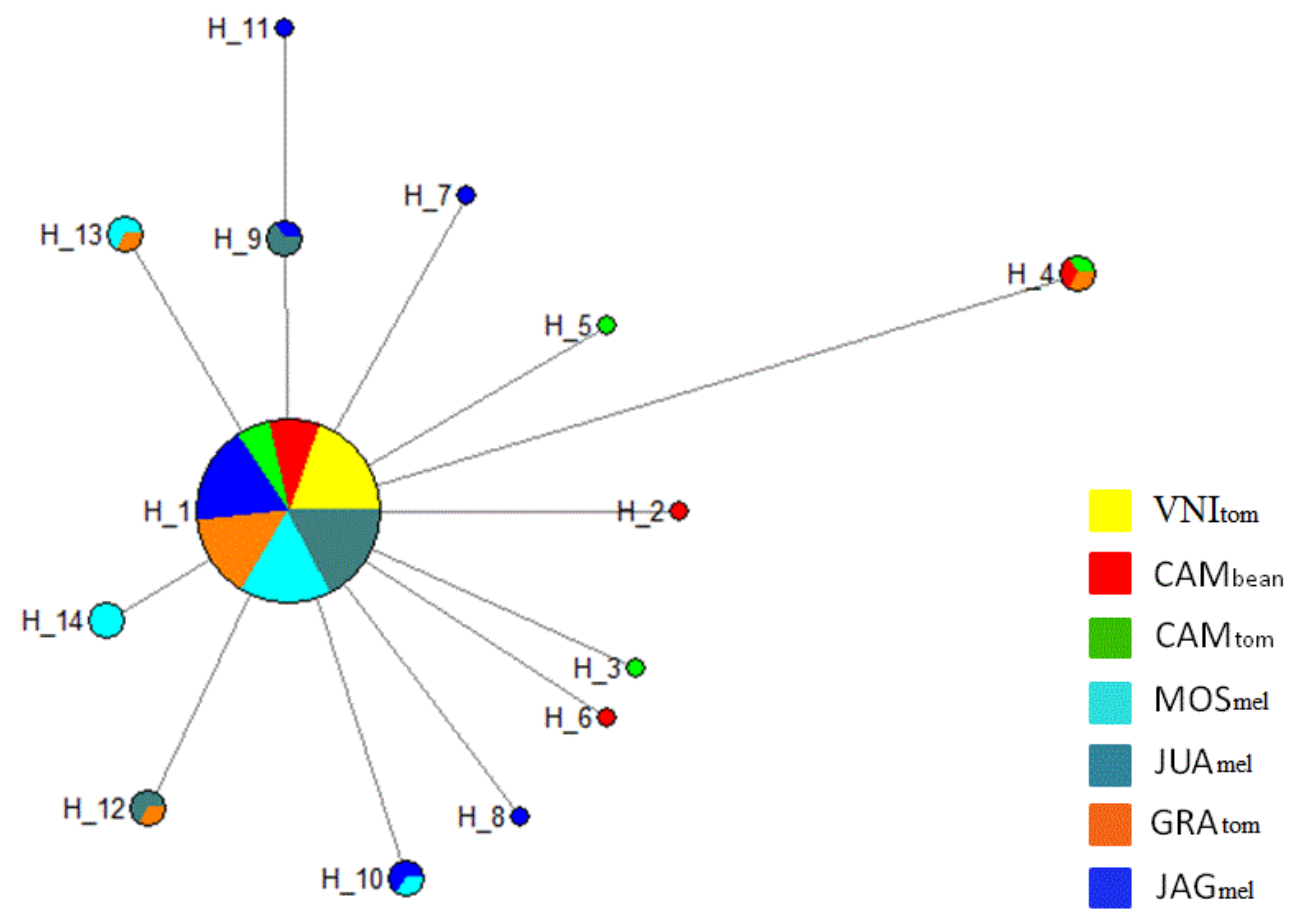

Figure 3. Haplotype network of Liriomyza sativae showing 14 interconnected haplotypes. The circle size is proportional to the number of individuals observed per haplotype. $\mathrm{VNI}_{\text {tom }}=$ Venda Nova do Imigrante-ES, host tomato; $\mathrm{CAM}_{\text {bean }}=$ Camocim de São Felix-PE, host bean; $\mathrm{CAM}_{\text {tom }}=$ Camocim de São Felix-PE, host tomato; $\mathrm{JAG}_{\mathrm{mel}}=$ Jaguaruana-CE, host melon; $\mathrm{GRA}_{\text {tom }}=$ Gravatá-PE, host tomato; $\mathrm{MOS}_{\mathrm{mel}}=$ Mossoró- Rio Grande do Norte, host melon; $\mathrm{JUA}_{\mathrm{mel}}=$ Juazeiro-BA, host melon.

Table 2. Neutrality tests and intra-population genetic diversity measures for each sample.

\begin{tabular}{cccccccc}
\hline Samples & Tajima's $\boldsymbol{D}$ & $\mathbf{N}$ & $\mathbf{H d}^{*}$ & $\boldsymbol{\Pi}^{*}$ & $\mathbf{N S}$ & $\mathbf{H}$ & $\mathbf{K}$ \\
\hline $\mathrm{VNI}_{\text {tom }}$ & 0.00000 & 16 & 0.00000 & 0.00000 & 0 & 1 & 0.00000 \\
$\mathrm{CAM}_{\text {bean }}$ & -1.74110 & 10 & 0.53333 & 0.00141 & 5 & 4 & 1.00000 \\
$\mathrm{CAM}_{\text {tom }}$ & -1.59524 & 8 & 0.64286 & 0.00177 & 5 & 4 & 1.25000 \\
$\mathrm{JAG}_{\text {mel }}$ & -1.58577 & 20 & 0.51579 & 0.00096 & 5 & 6 & 0.67895 \\
$\mathrm{GRA}_{\text {tom }}$ & -1.91084 & 15 & 0.37143 & 0.00094 & 5 & 4 & 0.66667 \\
$\mathrm{MOS}_{\text {mel }}$ & -0.86660 & 19 & 0.52047 & 0.00083 & 3 & 4 & 0.58480 \\
$\mathrm{JUA}_{\text {mel }}$ & -0.68482 & 18 & 0.39216 & 0.00059 & 2 & 3 & 0.41830 \\
\hline
\end{tabular}

Tajima's $D(* \mathrm{p}<0.05) ; \mathrm{N}=$ sample size; HD= Haplotype diversity $(0-1)^{*} ; \pi=$ nucleotide diversity $(0-1)^{*}$; $\mathrm{NS}=$ Number of polymorphic sites; $\mathrm{H}=$ Haplotype; $\mathrm{K}=$ average number of nucleotide difference; $\mathrm{VNI}_{\text {tom }}=\mathrm{Venda}$ Nova do Imigrante-ES, host tomato; $\mathrm{CAM}_{\text {bean }}=$ Camocim de São Felix-PE, host bean; $\mathrm{CAM}_{\text {tom }}=$ Camocim de São Felix-PE, host tomato; $\mathrm{JAG}_{\mathrm{mel}}=$ Jaguaruana-CE, host melon; $\mathrm{GRA}_{\mathrm{tom}}=$ Gravatá-PE, host tomato; $\mathrm{MOS}_{\mathrm{mel}}=$ MossoróRio Grande do Norte, host melon; $\mathrm{JUA}_{\mathrm{mel}}=$ Juazeiro-BA, host melon.

The highest $F_{S T}$ value identified was for the comparison between L. sativae $\mathrm{CAM}_{\text {tom }}$ and $\mathrm{VNI}_{\text {tom }}$ populations (Table 3 ). However, the $F_{S T}$ values were non-significant $(>0.4)$, which demonstrates a higher level of genetic conservation in these populations.

We also observed that the populations $\mathrm{CAM}_{\text {tom }}, \mathrm{CAM}_{\text {bean, }}$ and $\mathrm{GRA}_{\text {tom }}$ have retained a high level of genetic conservation that may be related to the geographic proximity of these populations (Table 4). Genetic diversity among populations was very low, which might be related to bottleneck events during introduction into a new environment (NEI, 2005). The first record of $L$. sativae in Brazil occurred in the late 1960s (NAKANO; WIENDL; MINAMI, 1967). Studies on insect pests have demonstrated that the reduction in genetic diversity is common in invasive species owing to the founder effect; however, this is not a limiting factor for the success of these species in a new environment (PUILLANDRE et al. 2008; AHERN; HAWTHORNE; RAUPP, 2009). 
E. C. B. FERREIRA et al.

Table 3. Genetic differentiation among populations, assessed through the parameter $F_{S T}$.

\begin{tabular}{llllllll}
\hline & $\mathrm{VNI}_{\text {tom }}$ & $\mathrm{CAM}_{\text {bean }}$ & $\mathrm{CAM}_{\text {tom }}$ & $\mathrm{JAG}_{\text {mel }}$ & $\mathrm{GRA}_{\text {tom }}$ & $\mathrm{MOS}_{\text {mel }}$ & $\mathrm{JUA}_{\text {mel }}$ \\
\hline $\mathrm{VNI}_{\text {tom }}$ & 0.00000 & & & & & & \\
$\mathrm{CAM}_{\text {bean }}$ & 0.04950 & 0.00000 & & & & & \\
$\mathrm{CAM}_{\text {tom }}$ & 0.09312 & 0.00000 & 0.00000 & & & & \\
$\mathrm{JAG}_{\text {mel }}$ & 0.01597 & 0.02352 & 0.03786 & 0.00000 & & & \\
$\mathrm{GRA}_{\text {tom }}$ & 0.00444 & 0.00000 & 0.00000 & 0.01523 & 0.00000 & & \\
$\mathrm{MOS}_{\text {mel }}$ & 0.06016 & 0.04438 & 0.05909 & 0.03544 & 0.01578 & 0.00000 & \\
$\mathrm{JUA}_{\text {mel }}$ & 0.04950 & 0.04101 & 0.06129 & 0.00114 & 0.00000 & 0.06704 & 0.00000 \\
\hline
\end{tabular}

$\mathrm{VNI}_{\text {tom }}=$ Venda Nova do Imigrante-ES, host tomato; $\mathrm{CAM}_{\text {bean }}=$ Camocim de São Felix-PE, host bean; $\mathrm{CAM}_{\text {tom }}=$ Camocim de São Felix-PE, host tomato; $\mathrm{JAG}_{\mathrm{mel}}=$ Jaguaruana-CE, host melon; $\mathrm{GRA}_{\text {tom }}=$ Gravatá-PE, host tomato; $\mathrm{MOS}_{\mathrm{mel}}=$ Mossoró- Rio Grande do Norte, host melon; $\mathrm{JUA}_{\mathrm{mel}}=$ Juazeiro-BA, host melon.

Table 4. Genetic differentiation among populations.

\begin{tabular}{llllll}
\hline Populations & Da & Dxy & Kxy & Ss & Sf \\
\hline $\mathrm{VNI}_{\text {tom }} \times \mathrm{CAM}_{\text {bean }}$ & 0.00000 & 0.00071 & 0.50000 & 0 & 0 \\
$\mathrm{VNI}_{\text {tom }} \times \mathrm{CAM}_{\text {tom }}$ & 0.00000 & 0.00088 & 0.62500 & 0 & 0 \\
$\mathrm{VNI}_{\text {tom }} \times \mathrm{JAG}_{\text {mel }}$ & 0.00001 & 0.00050 & 0.35000 & 0 & 0 \\
$\mathrm{VNI}_{\text {tom }} \times \mathrm{GRA}_{\text {tom }}$ & 0.00000 & 0.00047 & 0.33333 & 0 & 0 \\
$\mathrm{VNI}_{\text {tom }} \times \mathrm{MOS}_{\text {mel }}$ & 0.00003 & 0.00045 & 0.31579 & 0 & 0 \\
$\mathrm{VNI}_{\text {tom }} \times \mathrm{JUA}_{\text {mel }}$ & 0.00002 & 0.00031 & 0.22222 & 0 & 0 \\
$\mathrm{CAM}_{\text {bean }} \times \mathrm{CAM}_{\text {tom }}$ & 0.00011 & 0.00149 & 1.05000 & 3 & 0 \\
$\mathrm{CAM}_{\text {bean }} \times \mathrm{JAG}_{\text {mel }}$ & 0.00001 & 0.00120 & 0.85000 & 0 & 0 \\
$\mathrm{CAM}_{\text {bean }} \times \mathrm{GRA}_{\text {tom }}$ & 0.00006 & 0.00112 & 0.79333 & 3 & 0 \\
$\mathrm{CAM}_{\text {bean }} \times \mathrm{MOS}_{\text {mel }}$ & 0.00003 & 0.00115 & 0.81579 & 0 & 0 \\
$\mathrm{CAM}_{\text {bean }} \times \mathrm{JUA}_{\text {mel }}$ & 0.00002 & 0.00102 & 0.72222 & 0 & 0 \\
$\mathrm{CAM}_{\text {tom }} \times \mathrm{JAG}_{\text {mel }}$ & 0.00001 & 0.00138 & 0.97500 & 0 & 0 \\
$\mathrm{CAM}_{\text {tom }} \times \mathrm{GRA}_{\text {tom }}$ & 0.00007 & 0.00128 & 0.90833 & 3 & 0 \\
$\mathrm{CAM}_{\text {tom }} \times \mathrm{MOS}_{\text {mel }}$ & 0.00003 & 0.00133 & 0.94079 & 0 & 0 \\
$\mathrm{CAM}_{\text {tom }} \times \mathrm{JUA}_{\text {mel }}$ & 0.00002 & 0.00120 & 0.84722 & 0 & 0 \\
$\mathrm{JAG}_{\text {mel }} \times \mathrm{GRA}_{\text {tom }}$ & 0.00001 & 0.00097 & 0.68333 & 1 & 0 \\
$\mathrm{JAG}_{\text {mel }} \times \mathrm{MOS}_{\text {mel }}$ & 0.00003 & 0.00093 & 0.65526 & 0 & 0 \\
$\mathrm{JAG}_{\text {mel }} \times \mathrm{JUA}_{\text {mel }}$ & 0.00000 & 0.00078 & 0.55000 & 1 & 0 \\
$\mathrm{GRA}_{\text {tom }} \times \mathrm{MOS}_{\text {mel }}$ & 0.00001 & 0.00090 & 0.63509 & 0 \\
$\mathrm{GRA}_{\text {tom }} \times \mathrm{JUA}_{\text {mel }}$ & 0.00000 & 0.00076 & 0.54074 & 0.53801 & 0 \\
$\mathrm{MOS}_{\text {mel }} \times \mathrm{JUA}_{\text {mel }}$ & 0.00005 & 0.00076 & & 1 & 0 \\
\hline & & & 0 & 0 \\
\hline
\end{tabular}

$\mathrm{Da}=$ Number of net nucleotide substitutions per site between populations; $\mathrm{Dxy}=$ Average number of nucleotide substitutions per site between populations; $\mathrm{Kxy}=$ Average nucleotide pairwise difference between two populations; $\mathrm{Ss}=$ Number of shared polymorphisms between pairs of populations; $\mathrm{Sf}=$ Number of fixed differences between pairs of populations.

\section{CONCLUSION}

The phylogenetic analyses of DNA barcodes indicated existence of a single clade for L. sativae in the Brazilian populations, demonstrating absence of genetic structure. The correct taxonomic identification of a species of economic importance is essential for control strategy and for population genetics, among other factors. Our study demonstrated the importance of DNA barcoding as an effective tool in molecular identification of cryptic species such as L. sativae. 


\section{ACKNOWLEDGEMENTS}

This study was supported by Fundação de Amparo à Ciência e Tecnologia do Estado de Pernambuco (FACEPE) (APQ-0651-2.02/10) and Universidade Federal de Pernambuco.

\section{REFERENCES}

AHERN, R. G.; HAWTHORNE, D. J.; RAUPP, M. J. Founder effects and phenotypic variation in Adelges cooleyi, an insect pest introduced to the eastern United States. Biological Invasions, Boston, v. 11, n. 4, p. 951-971, 2009.

ALTSCHUL, S. F. et al. "Basic local alignment search tool". Journal of Molecular Biology, London, v. 215, n. 3, p. 403-410, 1990

BANDELT, H. J.; ROHL, F. P. Median-joining networks for inferring intraspecific phylogenies. Molecular Biology and Evolution, London, v. 16, n. 1, p. $37-48,1999$.

BLACKET, M. J. et al. DNA-based identifications reveal multiple introductions of the vegetable leafminer Liriomyza sativae (Diptera: Agromyzidae) into the Torres Strait Islands and Papua New Guinea. Bulletin of Entomological Research, London, v. 105, n. 5, p. 533-544, 2015.

BUSVINE, J. R. Cryptic species of insect disease vectors and their importance. Endeavour, London, v. 4, n. 3, p. 108-112, 1980

CLARK, A. R. et al. Invasive phytophagous pests arising through a recent tropical evolutionary radiation: the Bactrocera dorsalis complex of fruit Flies. Annual Review of Entomology, New York, v. 50, n. 1, p. 293-319, 2005.

COSTA-JUNIOR, C. R. L. et al. Genetic structuring and fixed polymorphisms in the gene period among natural populations of Lutzomyia longipalpis in Brazil. Parasites and Vectors, London, v. 8, n. 1, p. 193-202, 2015.

DE SOUZA FREITAS, M. T. et al. Phenotypic and genotypic variations among three allopatric populations of Lutzomyia umbratilis, main vector of Leishmania guyanensis. Parasites and Vectors, London, v. 8, n. 4, p. 448-458, 2015.

DELLA TORRE, A. et al. Molecular and ecological aspects of incipient speciation within Anopheles gambiae: the glass is half full. Environmental Science, Sofia, v. 289, n. 2, p. 115-117, 2002.

EDGAR, R. C. MUSCLE: multiple sequence alignment with high accuracy and high throughput. Nucleic acids resources, London, v. 32, n. 5, p. 1792-1797, 2004.

EWING, B. et al. Base-calling of automated sequencer traces using Phred. Genome research, New York, v. 8, n. 3, p. 175-185, 1998.

EXCOFFIER, L.; LISCHER H. E. Arlequin suite ver 3.5: a new series of programs to perform population genetics analyses under Linux and Windows. Molecular Ecology resources, London, v. 10, n. 3, p. 564-567, 2010.

FERGUSON, J. S. Development and stability of insecticide resistance in the leafminer Liriomyza trifolii (Diptera: Agromyzidae) to cyromazine, abamectin, and spinosad. Journal of Economic Entomology, London, v. 97, n. 1, p. 112-119, 2004.

GUINDON, S. et al. New algorithms and methods to estimate maximum-likelihood phylogenies: assessing the performance of PhyML 3.0. Systematic biology, London, v. 59, n. 3, p. 307-321, 2010.

GARIEPY, T. D. et al. Parasitoids, predators and PCR: the use of diagnostic molecular markers in biological control of Arthropods. Journal of applied entomology, Germany, v. 131, n. 4, p. 225-240, 2007.

HEBERT, P. D. N. et al. Biological identifications through DNA barcodes. Proceedings. Biological sciences / The Royal Society, London, v. 270, n. 1512, p. 313-321, 2003

JENKINS, T. A.; CHAPMAN, J. L.; MICALLEF, O. L. Molecular techniques for the detection and differentiation of host and parasitoid species and the implications for fruit fly management. Journal of Insects, New York, v. 3, n. 3, p. 763-788, 2012.

KIMURA, M. A simple method for estimating evolutionary rate of base substitutions through comparative studies of nucleotide sequences. Journal of Molecular Evolution, Germany, v. 16, n. 2 , p. 111-120, 1980.

KOX, L. F. F. et al. Identification of economically important Liriomyza species by PCR-RFLP analysis. Bulletin OEPP/EPPO, Paris, v. 35, n. 1, p. 79-85, 2005.

LIMA, T. C. C.; GEREMIAS, L. D.; PARRA, J. R. P. Efeito da temperatura e umidade relativa do ar no desenvolvimento de Liriomyza sativae Blanchard (Diptera: Agromyzidae) em Vigna unguiculata. Neotropical Entomology, Piracicaba, v. 38, n. 6, p. 727-733, 2009. 
MURPHY, S. T.; LASALLE, J. Review article: balancing biological control strategies in the IPM of new world invasive Liriomyza leafminers in field vegetable crops. Biocontrol News and Information, New York, v. 20, n. 3, p. 91-104, 1999.

NAKANO, O.; WIENDL, F. M.; MINAMI, K. Uma nova praga (Agromyzidae) da couve. Revista Agrícola, Piracicaba, v. 42, n. 1, p. 1-10, 1967.

NEI, M. Bottlenecks, genetic polymorphism and speciation. Genetics, New York, v. 170, n. 1, p. 1-4, 2005.

NELSON, L. A.; WALLMAN J. F.; DOWTON, M. Using COI barcodes to identify forensically and medically important blowflies. Medical and Veterinary Entomology, London, v. 21, n. 1, p. 44-52, 2007.

PANG, B.P. et al. Effects of different host plants on population parameters of Liriomyza sativae. Plant Protection, London, v. 31, n. 2, p. 26-28, 2005.

PARRELLA, M. P. et al. Control of Liriomyza trifolii with biological agents and insects growth regulators. California Agriculture, Richmond, v. 36, n. 11, p. 17-19, 1982.

PARRELlA, M. P. Biology of Liriomyza. Annual Review of Entomology, New York, v. 32, n. 76, p. 201-224, 1987.

POSADA, D. Jmodeltest: Phylogenetic Model Averaging. Molecular Biology and Evolution, New York, v. 25, n. 7, p. 1253-1256, 2008.

PUILLANDRE, N. et al. Genetic bottleneck in invasive species: the potato tuber moth adds to the list. Biological Invasions, Netherlands, v. 10, n. 3, p. 319-333, 2008.

REITZ, S. R; GAO, Y.; LEI, Z. Insecticide Use and the Ecology of Invasive Liriomyza Leafminer Management. 1. ed. Rijeka, Croatia: INTECH, 2013. $233 \mathrm{p}$.

ROZAS, J. et al. DnaSP, DNA polymorphism analysis by the coalescent and other methods. Bioinformatics, London, v. 19, n. 18, p. 2496-2497, 2003.

SAITOU, N.; NEI, M. The neighbor-joining method: a new method for reconstructing phylogenetic trees. Molecular Biology and Evolution, New York, v. 4, n. 4, p. 406-425, 1987.

SCHEFFER, S. J.; LEWIS, M. L. Mitochondrial phylogeography of vegetable pest Liriomyza sativae (Diptera: Agromyzidae): divergent clades and invasive populations. Annals of the Entomological Society of America, New York, v. 98, n. 2, p. 181-186, 2005.

SCHEFFER, S. J.; MATTHEW, L. L.; RAVINDRA, C. J. DNA barcoding applied to invasive leafminers (Diptera: Agromyzidae) in the Philippines. Annals of the Entomological Society of America, New York, v. 99, n. 2, p. 204-210, 2006.

SPENCER, K. A. Agromyzidae (Diptera) of Economic Importance. Netherlands. Series Entomologica. 1973. p. 418.

TAJIMA, F. Statistical method for testing the neutral mutation hypothesis by DNA polymorphism. Genetics, New York, v. 123, n. 3, p. 585-595, 1989.

TAMURA, K. et al. MEGA5: Molecular evolutionary genetics analysis using maximum likelihood, evolutionary distance and maximum parsimony methods. Molecular Biology and Evolution, New York, v. 28, n. 10, p. 2731-2739, 2011.

TOKUMARU, S. et al. Insecticide susceptibility of Liriomyza sativae, L. trifolii, and L. bryoniae (Diptera: Agromyzidae). Journal of Applied Entomology and Zoology, Tokyo, v. 49, n. 1, p. $1-10,2005$

WAN, N. F. et al. An ecological indicator to evaluate the effect of chemical insecticide pollution management on complex ecosystems. Ecological Indicators, New York, v. 53, n. 6, p. 11-17, 2015.

WANG, L. P. et al. Genetic variation of host populations of Liriomyza sativae Blanchard. Agricultural Sciences in China, Beijing, v. 7, n. 5, p. 585-590, 2008 .

WIEGMANN, B. M. et al. Episodic radiations in the fly tree of life. Proceedings of the National Academy of Sciences, London, v. 108, n. 14, p. 5690-5695, 2011.

WILSON, A. C. et al. Mitochondrial DNA and two perspectives on evolutionary genetics. Biological Journal of the Linnean Society, London, v. 26, n. 1, p. 375-400, 1985 